\title{
MAN AND BODY IN THE HISTORY OF THE MODERN AGE \\ REFLECTIONS ON AN INTERNATIONAL SYMPOSIUM IN BERLIN, 1-3 DECEMBER 1981
}

by

\author{
ARTHUR E. IMHOF*
}

I had had a strange experience. It occurred on the occasion of a scientific colloquium on the body in which I had lately taken part. We had continually searched for the object under discussion, but we couldn't find it anywhere. Instead of talking about the body, we discussed its components, its organs, this or that gesture as well as sequences of gestures. The discussion dealt with heads, arms, feet, all of which we observed with regard to the manner of eating, of greeting, of grooming. But the body, no, we never did meet up with it. (Michel de Certeau in an interview with Georges Vigarello concerning 'Histoires de corps', printed in Esprit, February 1982, p. 179.)

APPARENTLY it is the same for everyone. Ever since scientists from the most diverse disciplines discovered the body, the number of conferences, conventions, and colloquia dealing with it has multiplied. And everywhere the experience is the same: there is no such thing as the body. ${ }^{1}$ Four years ago, we had felt that this gave us good reason to complain, when we reported on a first symposium accompanying a research project at the Freie Universität in Berlin, entitled, 'Man and Health in the History of the Modern Age'. ${ }^{2}$ Invited to a further round-table discussion at the beginning of December 1981 were representatives of social history, of the history of "mentalités" and population, of medicine, art, and architecture, of folklore and ethnology, of historical

* Prof. Dr Arthur E. Imhof, Professor of Social History, Freie Universität Berlin, Habelschwerdter Allee 45, D-1000 Berlin (West) 33.

I am deeply obliged to the Volkswagenwerk Foundation in Hanover for its generous and understanding research support. The enormous costs in work and time on the material-related, technical side of the project was largely relieved by experienced field workers (for example, by two programmers). This allowed me to concentrate upon questions of content and granted the time for deliberating and stepping back from my own results as well as from the heated debates in the conferences and seminars accompanying the project.

\footnotetext{
' Of the growing number of such conventions (in Germany) with subsequent publications of the proceedings, I name only one because it is the most accessible: Dietmar Kamper and Christoph Wulf (editors), Die Wiederkehr des Körpers - Authentische Erfahrung oder Fiktion?, Frankfurt-am-Main, Suhrkamp, 1982. This is the publication of a portion of those contributions which were presented at an international symposium early in 1981 at the Max-Planck-Institute for Cultural Research in Berlin and which circled around such themes as 'The new consciousness of the body', 'Subjugation and resistance of the body', 'Newer body therapies', 'Art and body', 'Sexuality and body', 'Body experience and experiments'.

${ }^{2}$ Compare 'Mensch und Gesundheit in der Geschichte. Bericht über eine internationale Tagung in Berlin, 20.-23. September 1978', BerWissGesch, 1978, 1: 235-244. A continuation was published in the following year under the title. 'Conséquences et implications de l'allongement de la vie humaine depuis le XVII ${ }^{e}$ siècle'. Compare: 'Ursachen und Folgen der zunehmenden durchschnittlichen Lebenserwartung seit dem 17. Jahrhundert. Bericht über eine interdisziplinăre Tagung an der École des Hautes Études en Sciences Sociales, Paris, 24.-26. Oktober 1979', BerWissGesch, 1979, 2: 212-218. This conference also had a followup in a work convention held jointly with the German Centre for Age Questions on 5-7 July 1982, in Berlin. The theme was 'Gerontology and Social History. Ways to a Historical Consideration of Age'.
} 


\section{Man and body in the history of the modern age}

behavioural research, sociology, and physical anthropology, and of occupational, social, and preventative medicine from France, Scandinavia, Switzerland, West Germany, and Berlin. Although each of the three days was devoted to a firmly outlined theme concerning the body, thus endeavouring to counteract the parcelling of the body and body-related themes (see the convention programme with list of contributors, p. 406), it appeared that the speakers as well as those participating in the discussion were to a great extent infected by that development which has most drastically taken place in medicine.

After a long phase of humoral diagnostics, often based simply upon uroscopy and not requiring the patient's presence during the urine inspection, doctors actually did discover the body of their corporeal patients in the early modern period, even if the discovery was only temporary. Just as quickly, the body was once again lost sight of because doctors advanced under the skin, inside the body where it increasingly dissolved into its components: organs, tissues, cells, functions. With the steady accumulation of details, knowledge also increased, accompanied by a growing number of specialisms. In other disciplines relating to the body, similar developments have occurred. For this reason, it is no wonder that the body as a conference theme may be too large a unit, with the consequence that at most the term functions as an attractive common denominator.

My intention is not to give a general report on the convention of December 1981, the papers of which have already been published. ${ }^{3}$ I would prefer to reflect on several general considerations which have emerged from this series of meetings. This is appropriate because the second symposium was to be the last, being held at the end of a five-year project generously sponsored by the Volkswagen-Foundation.

Highly specialized conferences are necessary to advance scientific research. Such conferences should be on an international and multidisciplinary scale when the theme is something like 'Man and Health in the History of the Modern Age'. French historians of "mentalités" or historical demographers are years (if not decades) ahead of German researchers. Scandinavian and Swiss social historians have been occupied for a longer time with "history from below" on the strength of especially favourable source material and the unbroken tradition of these subdisciplines within the historical sciences in those countries. This means, among other things, a concern with such themes as the attitude of the ordinary people towards their bodies, life and limb, health and sickness, dying and death. Historians would be overtaxed if they wanted to handle on their own such topics as body symbolism, sexuality, literature on herbs, pastoral, ethno-, or social medicine. Each of these conferences stimulated us in its own specific way and yielded much in regard to each of our research projects: in terms of content, method, and critique. All of this is beyond question.

But sometimes it seemed to me that the essence of our theme was lost from sight

\footnotetext{
${ }^{3}$ Convention reports and similar items in AHF-Informationen, Nr. 3, 5 February 1982; Communications of the Federal Institute for Population Research, issue 1, 1982; Zeitschrift für Bevölkerungswissenschaft Demographie, 8, 1982; Norsk Bedrifts-helsetieneste, 3, 1982. All contributions have been published under the title: Leib und Leben in der Geschichte der Neuzeit, Berlin, Duncker \& Humblit, 1983. The revised contributions of the first symposium have been published: Mensch und Gesundheit in der Geschichte, Husum, Mathiesen Verlag, 1980, (Abhandlungen zur Geschichte der Medizin und der Naturwissenschaften, Nr. 3); of the second, held in Paris, Le vieillissement, Lyons, Presses Universitaires, 1982.
} 


\section{A. E. Imhof}

because of sheer analyses of details and heated debates over trivia. For example, is it really the quintessence of a long and intensive study of votive tablets ultimately to maintain that they offer only a limited insight into sickness and, above all, into the healing procedures of past centuries, and that they are unproductive as source material for popular medical practices? Votive tablets are expressive of the people's piety and trust in supernatural powers in past times. Is not the fact that there were these tablets, indeed, in impressively large numbers, more important and more essential to an understanding of our ancestors? In the case of the loss of health, the starting point was obviously to resort to this supernatural power before which one took a vow; with the return to health, this vow was acknowledged by donating a votive tablet. Confronted with this background information, what does it matter if the person was laid up with - by today's understanding - typhoid or spotted fever or tuberculosis of the lungs? Perhaps other "sacred" practices to which the people resorted as a third or fourth expedient and which competed with popular medicine were not documented in detail. As far as this goes, the balance drawn by a historian of "mentalités" would by no means be as negative as the cited judgement of the folklorist. It would appear to the researcher of collective historical behavioural modes that the question is falsely posed right from the start, since it proceeds from the same rational understanding of the body and of sickness that reigns today but which is, for the period under consideration, irrelevant.

Or, on another level, consider a discussion that goes on for hours about the roots of today's occupational medicine in the mining industry of past centuries. Does it not divert us from what is essential: that the farmers' manner of working and living, with all the grave bodily hardships belonging to it, simply constituted a negligible quantity for official medicine until the very recent past; neither is the question raised as to why this was so? This fact means no less than that the overwhelming majority of the population lay outside official medicine's field of vision. Against this simple background, two ideas suggest themselves: to connect the roots of today's occupational medicine with the aforementioned fact, and to raise the question of the geographical congruence between country areas totally lacking doctors or providing insufficient medical care and the more frequent appearance of votive tablet donations.

It is clear that today a wider public has a growing interest in things regarding the body. Many contemporaries jog; many have switched over to a qualitatively and quantitatively more reflective type of nutrition; anti-smoking campaigns are successful; more and more mothers are breast-feeding their children; tattooing is no longer something taboo; people are organizing themselves into self-help and experience groups and are increasingly taking into account the problems of the handicapped. Indeed, as has been mentioned, scientists have also discovered the body in the course of time. However, when the body is once again allowed to dissolve into its details, and when we do not want or are not capable of attempting syntheses or of clearly recording and making public larger connexions, then the wider public will hardly take notice of our meticulous, esoteric work; the body's return and our discovery of it will remain two separate things - and a chance will be wasted. A garish marketing or a clumsy simplification of fashionable body-related themes is not being supported here; but certainly I believe that highly specialized and complicated research should be made 


\section{Man and body in the history of the modern age}

accessible to interested outsiders.

The space here available does not allow for detailed exposition; therefore, I will limit myself to three points of general interest from the domain of the convention theme 'Man and Body in the History of the Modern Age'.

First, I should like to stress that today we deal with fundamentally different bodies from those considered by our ancestors in even the recent past. Our bodies are exposed to fewer aggressive and deadly elements of a hundred different sorts, and, therefore, they become, in general, considerably older. Our average life expectancy at birth has practically tripled in the course of the last century, at the beginning of adulthood it has doubled, and even at fifty or sixty considerably more years lie ahead of us than was formerly the case. Figure 1 shows in a three-dimensional computer picture the frequency distribution of about 40,000 deaths in the parish of Dorotheenstadt in Berlin between 1715 and 1875, according to the age at death. The first thing conspicuous in the picture is the immense wall farthest back signifying the number of infant deaths. About one-third (31.1\%) of those carried to the grave had not even reached their first year of life. If, in addition, deaths in all groups up to the age of eight are considered, then already half $(50.6 \%)$ of the children are registered. The rest of the deaths are distributed over the wide surface in the front portion of the picture if not in a completely even manner, nevertheless without that kind of massing in older age groups that we find today. This area of the computer picture records deaths among children, adolescents, persons in their prime, older people, and the aged. If the computer had also presented the following years up to 1982 in the same way, then we would scarcely be able to see anything. In this time period, the black wall in the back has shifted to the front and we can hardly see behind it. Formerly, one had the wall behind oneself; today, we - children, adolescents, persons in their prime, older people, and the aged - are all moving towards the wall. And yet, we do not want to acknowledge this.

Looking at infant mortality, it is conspicuous that there is a marked decline at the beginning of the nineteenth century, shortly after the introduction of smallpox vaccination everywhere in Europe. Nevertheless, it is just as conspicuous that the success was only temporary and that mortality did not simply reach the former level but quickly even surpassed it. We must bear in mind, of course, that we are dealing with absolute numbers and that Dorotheenstadt had greatly increased in size during this period. But even with a standardizing conversion of the yearly number of deceased infants per thousand live births, an impressive boom stands out, especially in the second half of the nineteenth century. If the causes of death are analysed in detail, one finds - as is presented in Figure 2 - that those infants and small children who had escaped smallpox were soon just as frequently victims of gastro-intestinal illnesses, primarily the notorious summer diarrhoea. In the course of explosive industrialization and urbanization, it became increasingly difficult for many (working) mothers to obtain proper nourishment, especially fresh cows' milk, for their little ones once they had been weaned, even if the mothers themselves had previously breast-fed them.

A fundamental question arising out of this background is: what happens when an 


\section{A. E. Imhof}

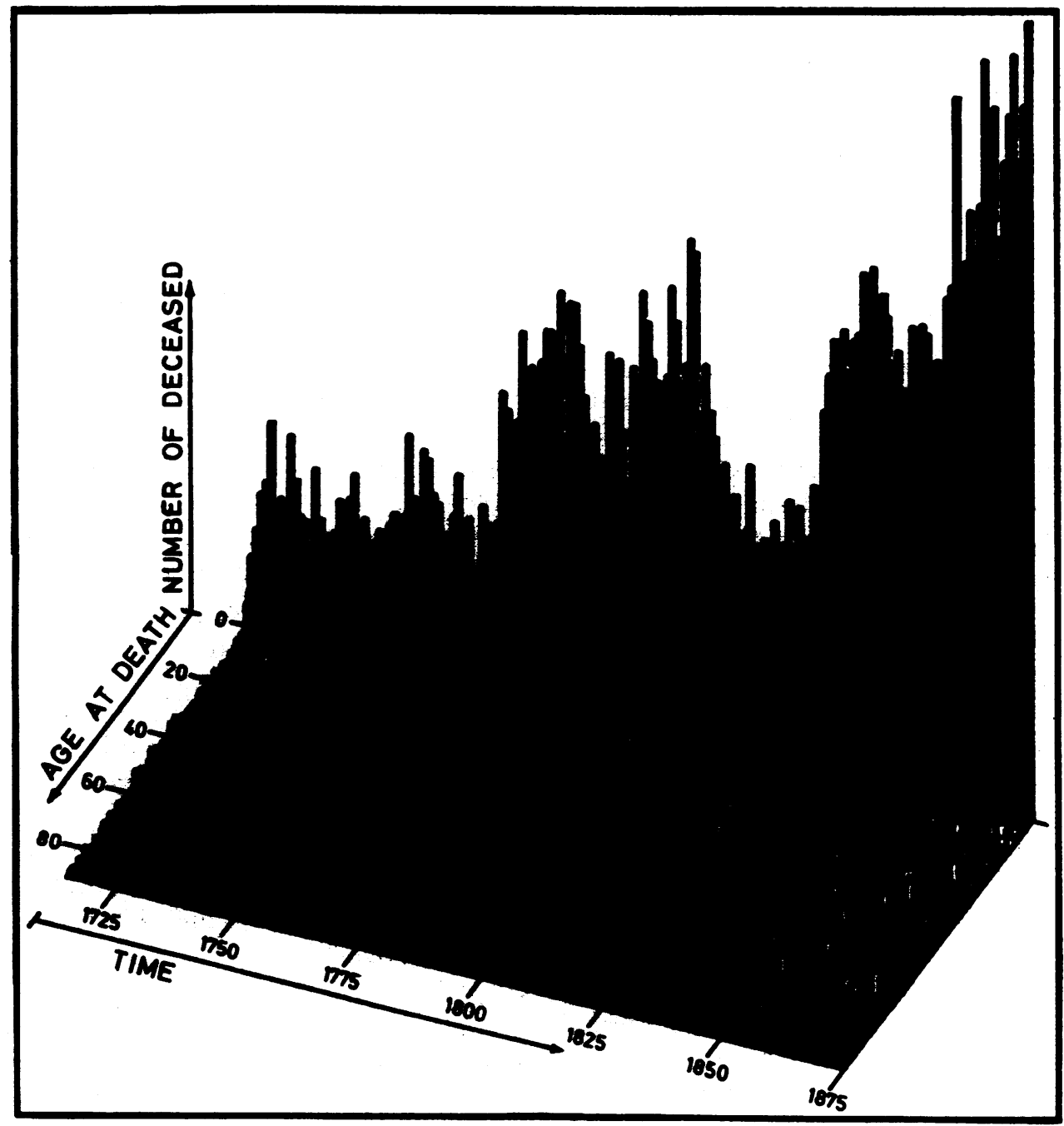

Figure 1. Age distribution of the deceased in the Berlin parish of Dorotheenstadt 1715-1875.

Deaths altogether $: 39.251(=100.0 \%)$

Among them, the 0-1 year olds: $12.193(=31.1 \%)$

Among them, the 0-8 year olds: $19.857(=50.6 \%)$

(Source: Computer data bank based upon the death registers of the parish of Dorotheenstadt; Evangelical Central Archive, Berlin (West).)

important cause of death disappears from a given mortality spectrum - once smallpox, today, for example, the malignant forms of cancer? This question is not simply a matter for epidemiologists and the preventive medicine people who discussed it during the convention; rather, it ultimately concerns all of us in a similar manner, specialists as well as non-specialists. We would be just as incapable of becoming immortal if we could eliminate cancer as one of our biggest killers as the infants were after the 


\section{Man and body in the history of the modern age}

introduction of smallpox vaccination. What would take the place of cancer for us? And would it be a "good exchange"?

The next change in the course of the nineteenth century occurred on another level no longer on the level of the "corps agresse" of the individual, as it was expressed at the conference, but rather on the level of the scientist observing this. The change did

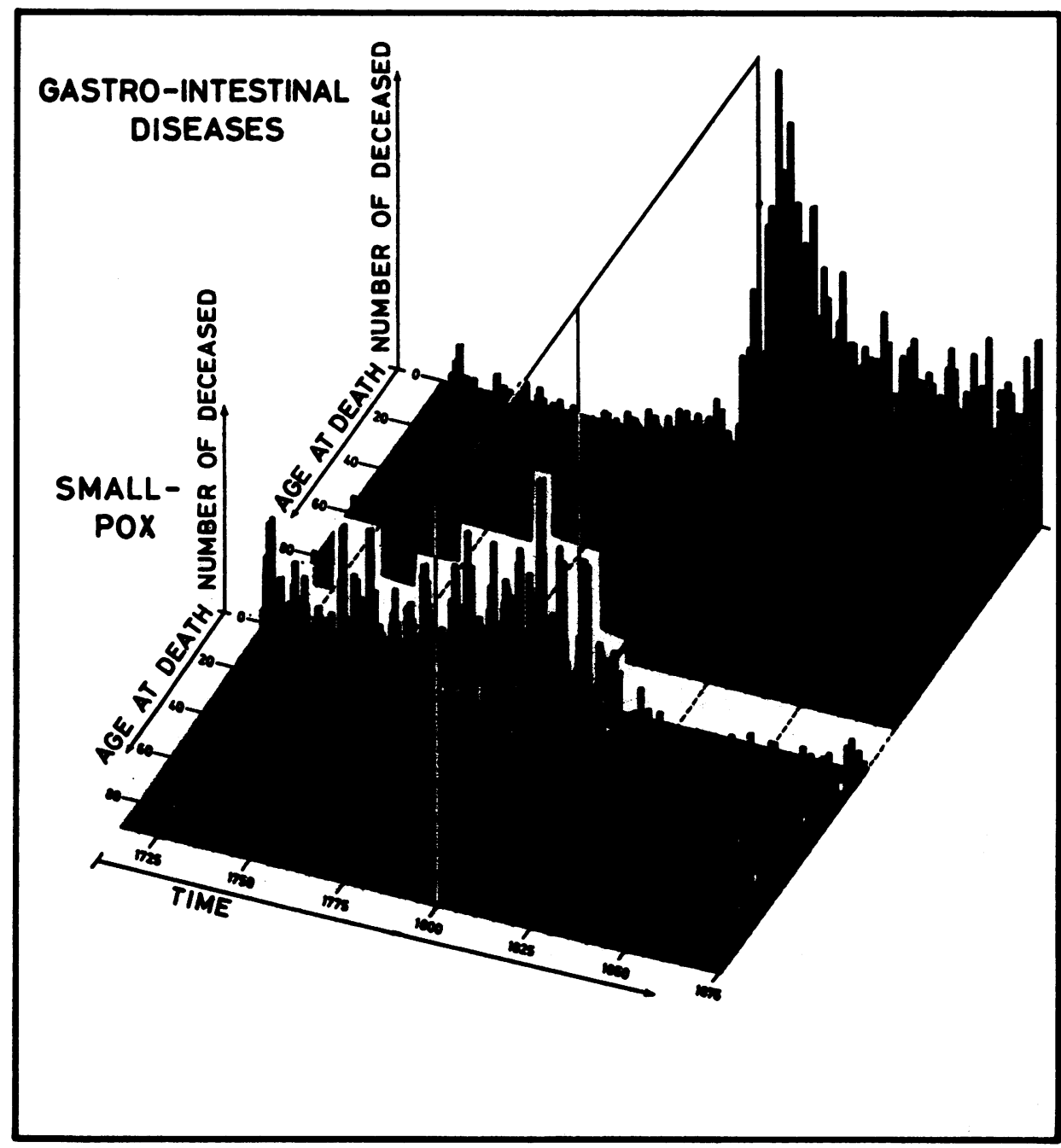

Figure 2. The "overtaking" of the smallpox cases of death among infants and small children at the beginning of the nineteenth century by increased deaths caused by gastro-intestinal illnesses. The collective term "gastro-intestinal" encompasses diagnoses - specific to this time period still very undifferentiated of constipation, diarrhoea, stomach cramps, etc. Of the total of 2014 cases of death subsumed under this term, "cramps" affected $1356(=55.5 \%)$, "diarrhoea" $370(=15.1 \%)$, and "abdominal inflammation" 288 $(=11.8 \%)$. Thus more than four-fifths $(=82.4 \%)$ of all "gastro-intestinal" causes of death are already recorded. (Source: Berlin Computer data bank, as in Figure 1.) 


\section{A. E. Imhof}

not consist in the weakening and ruining of the bodies of hundreds of thousands of infants in other ways, in other parts of the body, and by another illness. Rather, it was that older, less differentiated, larger body units noticeably dissolved in the course of the increasing medical advance concerning the body, which also led to a quantitative distinguishing of the causes of death (compare Figure 3). People no longer just symptomatically fell ill with stomach cramps, stomach constipation, or diarrhoea, but rather in a parcelled and differentiated manner with gastric-nervous fever, weakening of the stomach, stomach ulcer, stomach catarrh (chronic or acute), stomach cancer, stomach bleeding, organic stomach disease. This parcelling was perhaps interesting to the layman when there was thought to be a specifically effective therapy for this or that type of illness.

On the other hand, the case was different when cholera advanced from Asia to Europe in the 1830s. This new illness presented a previously unknown and, therefore, dangerous form of aggression against the body. It had, however, a rather modest effect on Dorotheenstadt, speaking in numerical terms (see Figure 4). Nevertheless, since this illness repeatedly overran the entire population, hitting all ages, groups, and social classes in a wave-like fashion, it not only had an individual, familial, or scientific-historical-medical parcelling significance, but also represented a threat to the entire community. The many individual "corps agressés" occurring at the same time in all social classes added up to a "société agressée".

\section{II}

In the most recent round-table discussion, as well as in previous ones, we referred to the body's significance in the past - a significance hardly imaginable today - as the "basis of the world of work, of happiness, of social and economic order" (see the programme, p. 406; the entire first day was devoted to this topic). Fitting as this might be for the former peasant society that did not have at its disposal fleets of machines or transport vehicles, for the craftsmen (literally translated from German: "Handworker"), for the soldiers not yet motorized, for those travelling by foot or by horse, such an account lets us easily overlook the fact that formerly the body and bodyrelated themes were not credited with the value which we place upon them today. This is seen especially strikingly in the source genre of medical topographies which have been minutely analysed in the research project. From this material, one can detect that in the second half of the eighteenth century and even during the nineteenth century there was a wide gap in body-related concepts between the doctor-authors on the one side who alone took responsibility in this area, and the common people on the other side whom the doctors often described in the gloomiest of terms: uneducated, unwashed, uncombed, filthily dressed, infected with lice, living in unsanitary huts. Formulations of the following kind wend through large numbers of these reports like red threads: "The apathy of the mothers towards their children's nourishment is great, especially in regard to breast-feeding. They sell the best cow milk while feeding themselves and their children a miserable water soup. They eat from filthy dishes. Cleanliness is inadequate. The parents are apathetic towards the expansion of their family. There is a great deal of resistance on the part of the population against medical measures, above all, against smallpox vaccination. A doctor is hardly ever 


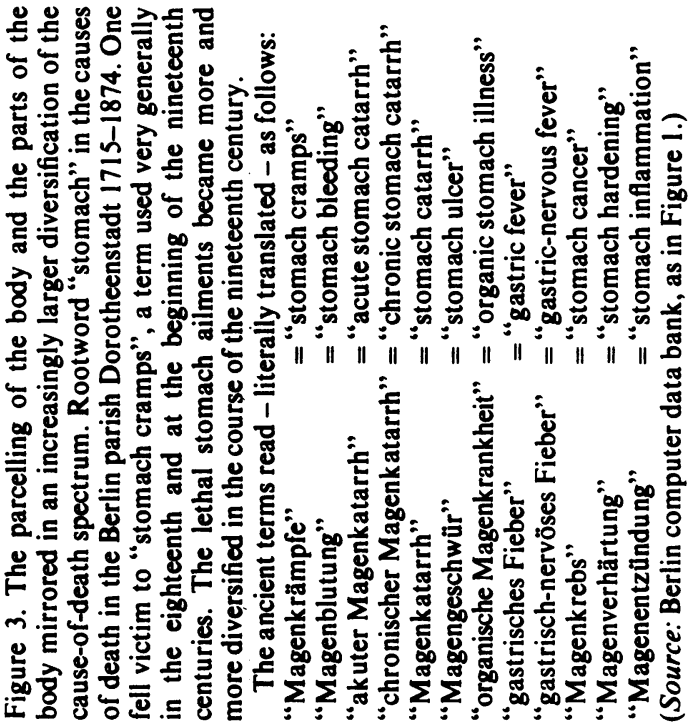

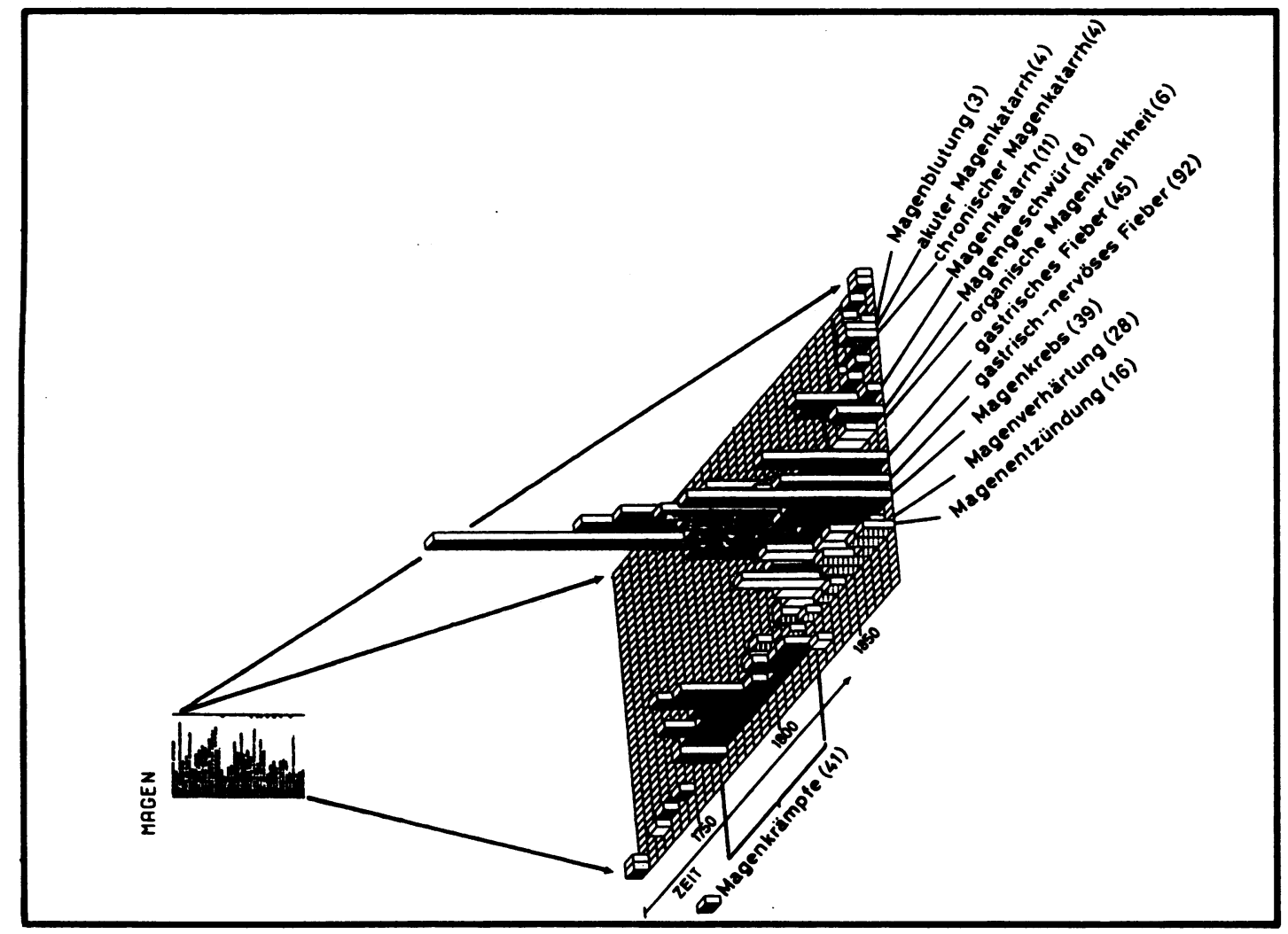




\section{A. E. Imhof}
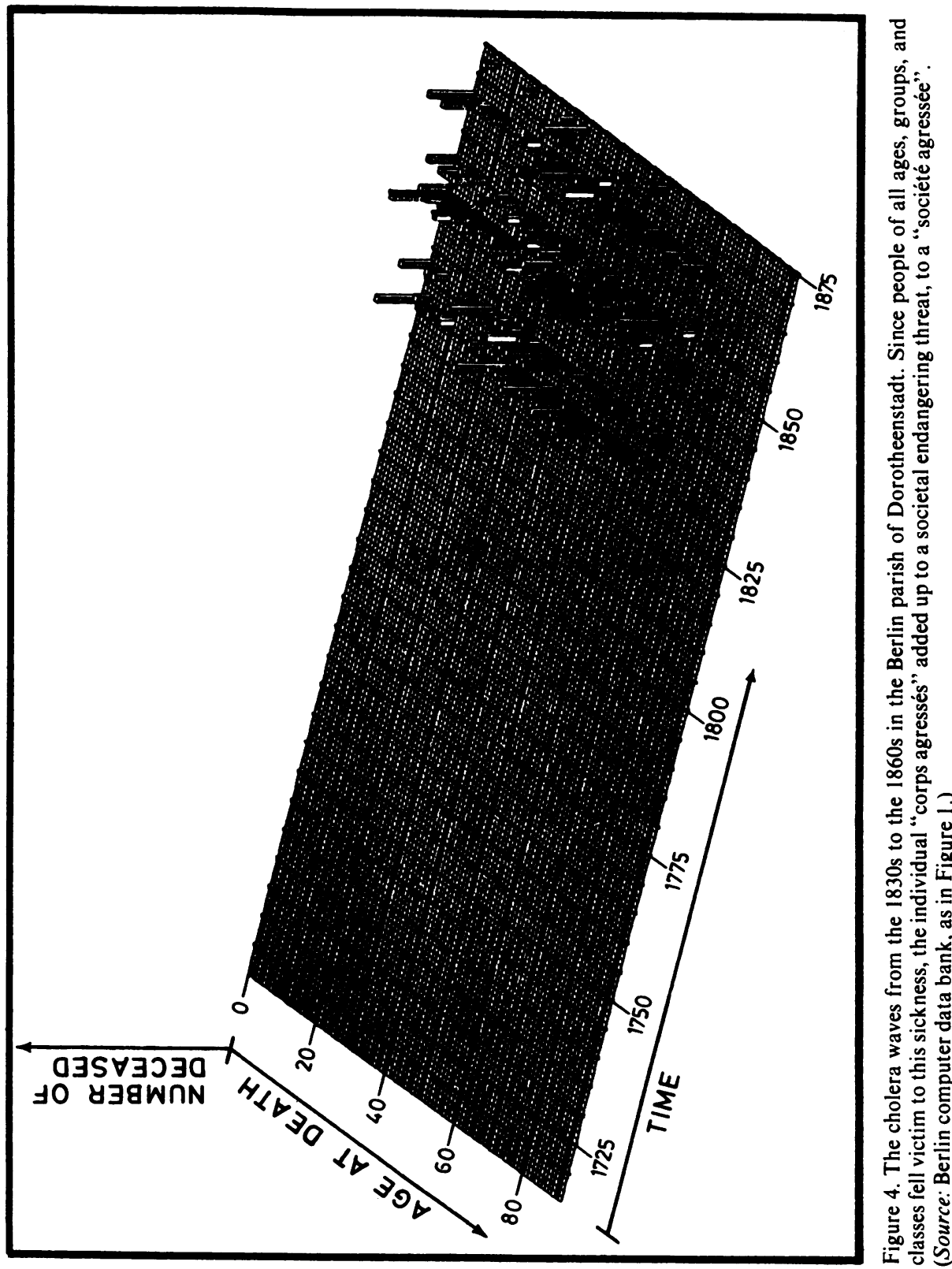


\section{Man and body in the history of the modern age}

called." (Quoted from the medical topographies for Würzburg 1805, for Ettlingen 1818, for Sigmaringen 1822, for Landau 1831, for the district court at Au near Munich 1837.)

If "body-related ideas" are integrated into the extended framework of "ideas in relation to life and limb" at all, then this apparent apathy, or, formulated less cuttingly, this inferior value given to earthly, corporeal things by our ancestors becomes clear and understandable. "Life" did not simply mean for them this earthly life, but, simultaneously and inseparably, eternal life. Confronted with or in expectation of an eternity beyond this earthly life, the length of the latter played a subordinate role. Today, when we often cast a disparaging glance upon the lower life expectancy of previous times, and are proud of the years of life won for most of us, this is possible only because we have simply forgotten that other dimension of life that formerly was more essential. Before we have doubled and trebled the length of our lives, we have reduced the course of life solely to the earthly phase through secularization. Even an increase to approximately seventy or eighty years in contrast to the previous twenty-five or thirty (at birth) is nothing in the context of a lost eternity. But it was only through this secularization of life that our bodies experienced just that enormous jump in value that helped them gain the importance they have today. This is because our lives having become longer in a more modest scope, but nevertheless now exclusively and conclusively earthly - depend quantitatively as well as, above all, qualitatively most closely upon the condition of our bodies - and undoubtedly the more so the longer they exist. Therefore, it is now reasonable to invest in the body and its best possible upkeep over many years.

\section{III}

The convention theme 'Man and Body' did not signify only "the Individual and his own Body", but simultaneously included the bodies of others, the relations between bodies, for example, between mother and child, between the handicapped and the nonhandicapped, between marriage partners. I would like to take an example from this area in suggesting the essential point that today we deal with different bodies in regard to partner-relationships than did our ancestors.

Considering again Figure 1, it is easy to understand that completely different constellations of generations and life courses arose because death knocked at the door of any person, regardless of his age. Since some persons only reached the age of twenty, others, however, the age of forty, sixty, or eighty, standardized patterns of life among those born in the same year hardly ever came into being - patterns like the ones we see today that are practically exchangeable among members of the same birth group. Previously, the childhood phase might have been over at sixteen for a person whose father was a victim at forty of an epidemic, because then the farm was free and the path to marriage was open. For another, the "same" phase lasted perhaps two or three times as long with the result that he could get married at fifty at the earliest. For this reason, when abstractly determined values of approximation (approximate mean age at marriage, approximate mean length of marriage, etc.) are given, one must continually consider the unusually large deviations from the standard occurring in those times. An approximate mean age of twenty-six with respect to men entering marriage for the 


\section{A. E. Imhof}

first time could have come about because the one man was twenty-five and the other was twenty-seven, or it could just as well have been that the one was sixteen and the other thirty-six. If the approximate mean age of the women entering into marriages with these men was twenty-four, the partners could in one case be of the same age, in another case, however, there could be a generation between them.

That the second case is nothing out of the ordinary, emerges distinctly from Figure 5. The age of each woman entering marriage for the first time in the Oberhessian village, Heuchelheim near Giessen, between 1691 and 1900 is represented in the left half of the graph with a point. The age interval between men and women entering marriage for the first time is entered on the right for four periods chosen out of this same space of time. Following from top to bottom the development over a good two hundred years, an enormously wide, scattered area can be detected in the beginning which in the course of time, however, visibly bundled up. The more that death was pushed back from the younger age groups and that people reached an increasingly later age in life, the more the life courses became similar to each other and the individual phases increasingly homogeneous. The individual marriage age (age of widowhood, age of death, etc.) increasingly corresponded to the collective approximation, and the age difference between partners became increasingly smaller. Unlike pairs are the exception today; a hundred years ago there were dozens of them. Formerly, partners dealt with bodies of differing age, whereas today we deal with bodies of about the same age. In those times, reciprocal physical attraction could have only seldom been the basis for long-term unions; other values were more decisive. The development that stands out in Figure 5 towards bodies of similar ages seems to have been an essential precondition for the change that is sometimes referred to a bit exaggeratedly as the "revolution" in sexuality, in affectivity, in intimacy, and in the romantic love between partners in the modern age.

Altogether it seems to me that we should not hurry to do the same as the medical people, which means hastily and industriously to dissolve the body into its components, having hardly had the time to discover it. I would much sooner suggest the reverse: rather than considering it detached, it is to be integrated in the larger framework of reference of life and limb and is to be left there as it is. But even if we "only" reflect on the body, it gives us, in my opinion, enough occasion and reason to think about, without parcelling, basic changes of the types that have been sketched here. 


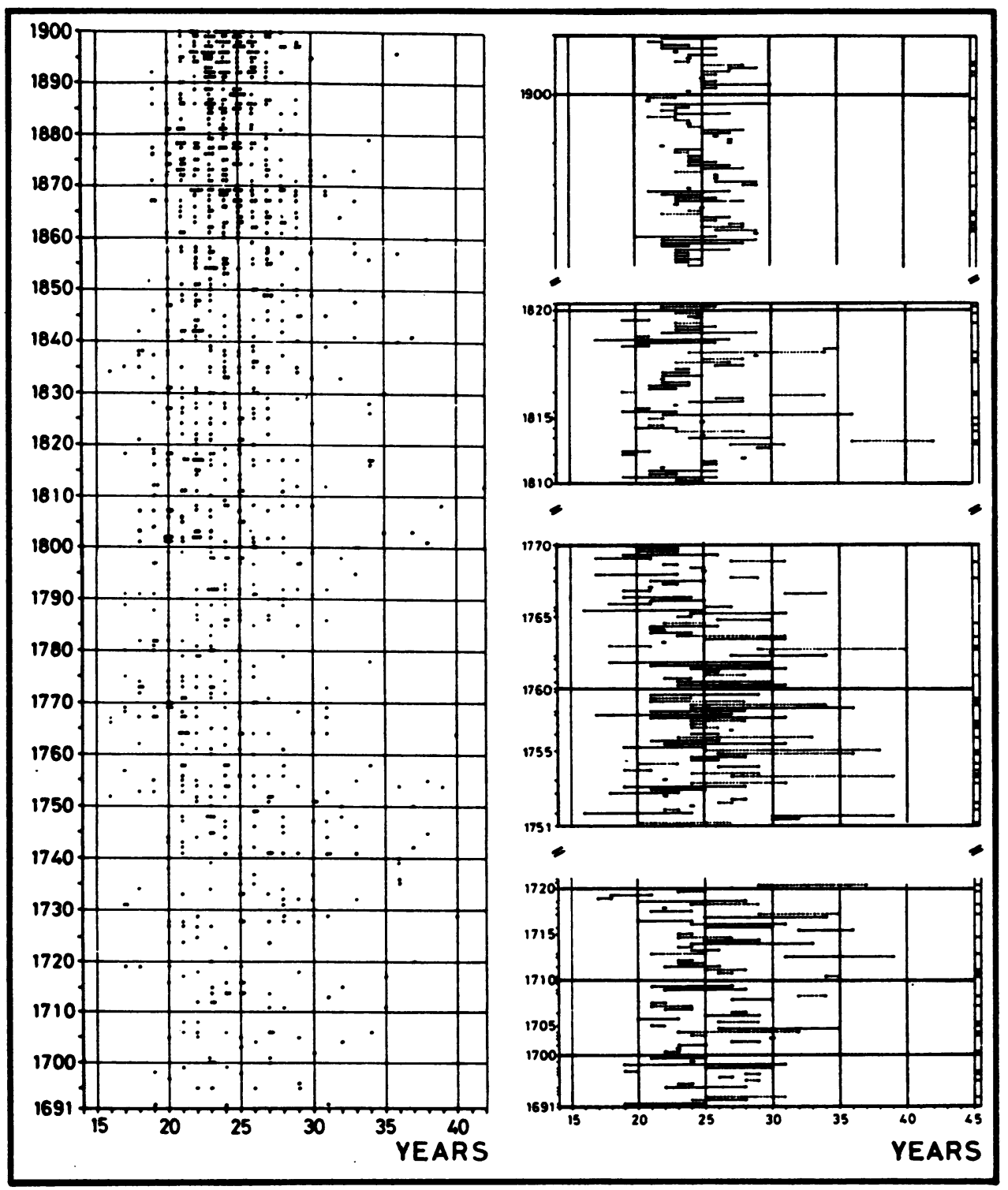

Figure 5. Age distribution of women at first marriage (left) as well as age differences between partners marrying for the first time (right; a line means that the man was older; a dotted line means that the woman was older) in the Oberhessian village of Heuchelheim near Giessen 1691-1900. The increasing bundling of the large scattered area at the beginning resulted in basic changes of the partners' physical relations.

(Source: Historische Demographie als Sozialgeschichte. Giessen und Umgebung vom 17. zum 19. Jahrhundert, Darmstadt and Marburg 1975, Figures 1 and 5b, pp. 317-323, 362-363.) 


\section{A. E. Imhof \\ CONVENTION PROGRAMME}

1st Day: The body: Basis of the world of work, of happiness, of social and economic order

Arthur E. Imhof (social historian, Berlin): 'Life and limb of our ancestors: a rhythmized world'

François Lebrun (historian of "mentalités”, Rennes): 'L'intervention des autorités face aux crises de mortalité dans la France d'Ancien Régime'

Maria Blohmke (doctor of social, occupational, and preventive medicine, Heidelberg): 'Impairment of the body's well-being seen by a doctor of occupational and social medicine'

Øvind Larsen (doctor of occupational and preventive medicine, and medical historian, Oslo): 'Occupational medicine or social medicine?'

Ekkehard Schröder (doctor and folklorist, Heidelberg): 'An ethno-medical view of man and his body'.

2nd Day: Of the employment of the body in the social context

Utz Jeggle (folklorist, and historian, Tübingen): 'Age and the experience of body'

Erdmann Weyrauch (modern historian, Bochum): 'Observations on the social culture of eating and drinking in class society'

Henning Eichberg (historical behavioural researcher, Stuttgart): 'Performance between walls - Parcelling of the body on the part of sports'

Robert Muchembled (historian of "mentalités", Lille): 'Le corps, la culture populaire et la culture des élites en France (XVeXVIII ' siècles)'

Alain Croix (historian-demographer and historian of "mentalités", Poitiers): 'L'homme et son corps dans l'Au-delà'.

3rd Day: Repressing, medicalizing, hygieneizing, antiseptisizing the body and bodyrelated things (eighteenth to twentieth centuries)

Jan Brügelmann (modern historian, Berlin): 'Medicalization of the small child and adult in Germany around 1780-1850; based upon medical topographies'

Geneviève Heller (art and architectural historian, Lausanne): 'Idéologies et rituels de la propreté aux $\mathrm{XIX}^{\mathrm{e}}$ et $\mathrm{XX}^{\mathrm{e}}$ siècles'

Bernd Herrmann (biologist and physical anthropologist, Göttingen): 'Development and effects of aesthetic principles in the biology of the human body'

Claudia Honegger (sociologist, Frankfurt-am-Main): 'Considerations concerning the medicalization of the female body'

Esther Fischer-Homberger (historian of psychiatry and medicine, Berne): 'Women and disease'. 